\title{
UMA VIAGEM POR IBIAMORÉ, O TREM FANTASMA
}

\author{
Valéria Brisolara Salomon
}

RESUMO:This text invites the reader to set off on a journey through Ibiamoré, o trem fantasma, a novel by Roberto B. Martins. This trajectory does not aim at the finish line, at exhausting the novel, but at taking one, among the many possible ways along the novel, which I hope will open doors to many journeys to come. Nevertheless, in order to accomplish this travel, it is necessary that we stop at some stations and speak of some of the many passengers of this train that all of us will once take: the train of the night or the train of death.

PALAVRAS-CHAVE: Viagem, Romance.

A PARTIDA

$A$ vida só pensa em morrer.

(LACAN, 1987, p. 293)

Aquele que parte não é nunca o mesmo que regressa.

(IANNI, 1990, p. 19)

Valéria Brisolara Salomon é Mestre em Letras pela Universidade Federal do Rio Grande do Sul, Doutoranda em Letras pela Universidade Federal do Rio Grande do Sul, Professora do Centro Universitário La Salle. 
Ler um romance é sempre fazer uma viagem, mas Ibiamoré, o trem fantasma é indubitavelmente um romance que nos convida a fazer, não uma, mas muitas, viagens paralelas pois a viagem está em diversos níveis do romance. Está inicialmente posta em seu título enigmático que remete tanto a um deslocamento de trem, algo não mais possível a nós gaúchos quanto a uma lenda ainda presente no imaginário de muitos gaúchos. A viagem está também nos inúmeros personagens viajantes, fugitivos, alguns até nômades, mas todos provocadores de estranheza e fascínio que tomam o trem fantasma de Roberto Bittencourt Martins. Está na trajetória que o romance simula e convida o leitor a fazer atravessando um mítico Rio Grande do Sul a fim de buscar mais detalhes sobre a lenda do trem fantasma e de seus narradores. Portanto, é o trilho que liga todas as estações do romance e conduz o leitor ao longo da narrativa.

A idéia do estranhamento com o outro, tão característica da viagem, também permeia todo o romance, pois os personagens de Ibiamoré, o trem fantasma são muitas vezes estrangeiros, mesmo que muitas vezes sejam estrangeiros em si mesmos, não se reconhecendo em suas próprias vidas, como Afonso Inácio, "estrangeiro ao mundo, viajando em si mesmo" (MARTINS, 1981, p. 23). Personagens construídos por um hábil narrador em terceira pessoa que parece saber mais do que nos conta, eles perdem-se em suas idiossincrasias e conflitos. Antes de serem gaúchos, são seres humanos e portanto faltantes. O narrador os descreve incessantemente e não os deixa falar, e em inúmeros momentos parece tomado por uma ânsia de descrever os "thôma" não da paisagem, mas desse outro que o fascina e ao mesmo tempo o revela a nós aos poucos até descobrirmos sua identidade no final do romance. De acordo com François Hartog, a medida dos "thôma" é dada pelo viajante, pelo cronista que interpreta o mundo a sua volta (HARTOG, 1999, p. 250). No nosso caso ela nos é dada por nosso narrador, que fala tanto de si e da sua necessidade de narrar, quanto das alteridades por ele descritas. É uma viagem, mas como Octavio Ianni lembra-nos, a viagem pode ser tanto um modo de descobrir o "outro" quanto um modo de descobrir o "eu" (IANNI, 1990, p. 3). Escrever uma narrativa é também embarcar em uma jornada, "inventando o outro, recriando o eu" (IANNI, 1990, p. 3) e sempre questionando se quem escreve é "o eu ou o outro?", como lembra-nos Michel Schneider (SCHNEIDER, 1990, p. 37) fazendo um jogo de palavras em francês entre as palavras autor (auteur) e outro (autre).

Por isso convido, assim como Martins o fez, meus leitores a embarcarem em uma análise de Ibiamoré, o trem fantasma. Essa trajetória que se inicia agora não tem por ponto de chegada a exaustão do romance, muito pelo contrário, iremos percorrer um, entre os muitos caminhos possí- 
veis e este abrirá portas para futuras jornadas. Para tanto se faz necessário que nos detenhamos em algumas estações e falemos de alguns dos muitos passageiros deste trem que todos um dia tomamos. $\mathrm{O}$ trem da noite. $\mathrm{O}$ trem da morte. Porque, como Lacan certa vez lembrou-nos que, em Além do Princípio do Prazer, Freud define que "A vida é um embolamento, um bolor, ela não se caracteriza por nada a não ser sua aptidão à morte" (LACAN, 1987, p. 292).

Boa viagem.

\section{AS ESTAÇÕES E OS PASSAGEIROS}

Caminante, no hay camino, se hace camino al andar Antonio Machado

Partimos para nossa jornada pelos campos de Ibiamoré assistindo uma cena ainda típica no interior de nosso estado, mas que já começa a desaparecer de muitos de nossos pagos, pois remete a um tempo mítico da história dos pampas quando não havia fronteiras, porteiras ou trens, quando os pastos eram "pastos não demarcados" (MARTINS, 1981, p. 19). É inverno e faz frio na campanha, é um tempo de espera, e no galpão há um fogo aceso e um grupo de homens ao redor desse fogo para escutar um velho contar estórias. O ancião pega o violão e começa a entoar uma cantiga fazendo referência ao trem fantasma dos campos de Ibiamoré. Todos ouvem o velho homem atentamente e a narrativa parte desse momento, com a simulação de uma viagem física por 11 estações pelo nosso estado por onde o leitor é convidado a percorrer. Este convite é ao mesmo tempo um convite a uma partida e a um retorno por regiões talvez esquecidas, algumas, talvez, dentro de nós mesmos.

Essa jornada prossegue até a última página do romance, onde há a retomada da página inicial e da cena nela descrita, mas o gaúcho e o sul já não são mais os mesmos no fim do romance. Continua fazendo frio lá fora do galpão, mas o fogo já não aquece mais. As chamas que queimavam num jogo, numa brincadeira com as brasas, agora, "cessam o jogo, já não brincam nas brasas" (MARTINS, 1991, p. 331). O velho ainda canta, mas ninguém o escuta mais. Todos o abandonaram. Sua voz vai morrendo, como morreram as brasas e ele finalmente não consegue mais entoar o poema. É o trem da noite chegando para o velho índio e para as lendas que precisam ser contadas. 
Esse poema apresentado nas cenas iniciais e finais do romance aponta para a estrutura circular da obra, que remete à circularidade dos ciclos vitais. Além disso, também sugere a necessidade de que estórias sejam contadas, ou cantadas, de que não deixemos o fogo morrer. Martins parece concordar que "não pode haver futuro para quem cortou todo laço com seu passado", palavras de Ricardo Goldenberg referindo-se à análise de Daniela Ropa sobre Blade Runner (GOLDENBERG, 1994, p. 89).

A narrativa que Martins nos oferece é delimitada por estes dois momentos em que o velho homem entoa suas cantigas. Não sendo organizada em ordem temporal, ela é inteiramente regida pelo princípio da associação livre, que pressupõe o conhecimento e aceitação da existência de uma lógica própria do inconsciente. Todos os capítulos do livro, ou estações, mantêm uma ligação com o anterior e o próximo, embora essas ligações não sejam sempre óbvias e muitas vezes sejam descobertas pelo leitor muitas páginas depois de terem sido realizadas. As ligações associativas feitas pelo narrador conduzem o leitor de uma estação à outra. Martins propõe uma organização não-linear às histórias que conta e o leitor é convidado a participar desse processo associativo e tentar desvendar os elos que ligam cada estação e cada personagem. Esta forma de organização do romance, regida pelo principio associativo, está certamente relacionada com o fato de que o inconsciente desconhece tempo. Heloísa Fernandes lembra-nos que o inconsciente "não possui critérios de localização espaço-temporal, nem é acessível à função do tempo e, por isso mesmo, desconhece a contradição" (FERNANDES, 1988, p. 14). Desta maneira, a melhor maneira de falar sobre a narrativa de Martins, também parece ser usando o método associativo, e é assim que prosseguirei, começando com exemplos de como o romance é construído.

Um bom exemplo de como a narrativa é habilmente construída encontra-se na transição entre as seções I e II. Uma das personagens mais importantes do romance, o Padre Cortoxines, está corrigindo trabalhos de alunos e é surpreendido por uma resposta totalmente errônea de um de seus alunos. Padre Cortoxines procura o nome do aluno no cabeçalho da prova e tenta lembrar-se do rosto do menino que supõe imbecil, este se chama Carlos Almagre. Conclui que esse menino nunca será nada da vida e continua refletindo sobre o vazio de sua vida e sobre as provas que ainda tem que corrigir. Padre Cortoxines e Carlos Almagre desaparecem da narrativa dando lugar a outros personagens de vida igualmente vazia e quando quase já não nos lembramos mais deles, muitas páginas adiante, temos um capítulo onde vemos um Carlos Almagre ainda menino e nem um pouco imbecil. Essa passagem é ilustrativa da maneira associativa da construção romanesca de Martins, mas há outras semelhantes. Há uma rápida e apa- 
rentemente ocasional menção a Gastonville na página 93 da parte III. O capítulo transcorre normalmente, mas a parada seguinte é, não coincidentemente, Gastonville. Então, quanto encontramos novamente esse nome de cidade afrancesado, ele já nos parece familiar. Ainda, a epígrafe desse capítulo é retirada do capítulo anterior, acentuando a relação entre os capítulos. Exemplos como estes abundam na narrativa de Martins, mas o importante é que percebamos que não são acidentais, estão intimamente relacionados ao tema que Martins trata e as escolhas formais que ele faz adequando a forma aos temas.

A cada uma das paradas embarcam novos passageiros. Cada um com suas singularidades, mas todos têm seus caminhos atravessados pelo trem e estão de alguma maneira relacionados, mesmo sem saberem, com outros que embarcam na narrativa. O que nos interessa aqui são as semelhanças e diferenças entre eles. Não há pessoas desinteressantes na narrativa de Martins, pois todos têm seu interesse e sua magia, e ao mesmo tempo todos são puramente humanos e dotados das mesmas fraquezas que os fazem sentir vazios e faltantes. Todos têm uma história que, se não justifica seus atos, pelo menos os explica e fazem-nos dignos de afeição. Carlinda, a jovem molestada por José João Cohimbra torna-se "Dona Carlinda", "muñequera" e "bruxa" e não chegamos a ter raiva dela. O aluno burro que padre Cortoxines xinga por responder erradamente a uma pergunta de história, não por acaso, é Carlos Almagre. O menino descobridor do segredo de Dona Carlinda. Essa mesma Carlinda é uma das personagens centrais da estação Santa Joana, cujas linhas iniciais são as mesmas linhas do livro que Almagre iria escrever anos mais tarde e intitular "A Bergamoteira".

O capítulo intitulado Carlinda Campos inicia: "Carlinda Campos viveu dias vidas, não simultâneas mas consecutivas. A segunda é confusa e vaga, feita de retalhos e de fantasias, vivida mais na imaginação do que na realidade; na primeira, teve a existência comum das mulheres de seu tempo na pequena Santa Joana do início do século" (MARTINS, 1981, p. 40). Na primeira foi uma moça que gostara de bonecas, mas havia abandonadoas para dedicar-se ao casamento e filhos. Com o nascimento de duas filhas, pode retornar à fabricação das bonecas de pano, e era essa extraordinária habilidade em confeccionar as bonecas que a diferenciava de todas as outras mulheres e seria o embrião da segunda Carlinda. Quando já não tem mais filhas pequenas, é conhecida por "muñequera" e "bonequera", a fabricante de bruxas de pano, que chamava carinhosamente de "guriazinhas", atribuindo-as caráter de humanas e enchendo um quarto inteiro com elas. Todos, incluindo o narrador, questionam-se se seria tudo apenas "excentricidades de uma velha" (MARTINS, 1981, p. 46) ou talvez loucura. Mais tarde, a descoberta. Carlinda era "a dona da cidade", "a senhora de todos, 
da vida e da morte, de toda a cidade (MARTINS, 1981, p. 48). Carlos Almagre havia descoberto seu segredo. A miniatura da cidade em seu jardim não era apenas decorativa. Carlinda brincava de Deus com a vida das pessoas. Decidia quem devia morrer e retirava de seu jardim. Dava a vida e a morte a todos, controlando o destino, agindo como se todos fossem peões em seu tabuleiro. Um Almagre adulto já tem dúvidas do que havia visto, pois "O tempo, contudo, faz com que duvide de si mesmo. Terá sido verdade?" (MARTINS, 1981, p. 48). O passado e o presente misturam-se na narrativa de Martins como interpolam-se na nossa vida diária, onde todos temos mais de uma existência.

Mas não foi só essa personagem de nome Carlinda que teve duas existências em Ibiamoré. O mesmo Carlos Almagre adulto escreve dois necrológicos para seu amigo Ramiro e fala da morte e do destino. Ele conclui que o amigo teve "A vida irremediavelmente cortada, os dias não vividos para sempre, o futuro não deixado acontecer, o rastro inexistente, o fim de tudo" (MARTINS, 1981, p. 60), como se a mão de dona Carlinda houvesse retirado-o da vida. Portanto, mesmo adulto e duvidando das cenas que havia visto no jardim de dona Carlinda, ainda parecia acreditar em uma mão que cortava o fio da vida como aquela da misteriosa bonequeira.

Outro viajante, Padre José Maria Sampaio, refletindo sobre sua vida, também tem a sensação do tempo perdido e de duas vidas diferentes dentro da sua. Na terceira parada, Solidões, a sua história é contada. Ela havia ido para a paróquia longínqua de Ibiamoré, passando por Santa Joana dentro da diocese de Solidões. Após chegar ao povoado e conhecer sua paróquia, começou a perceber que algo faltava, sentia "uma certa sensação de que o terreno não ficava reconhecido; de que algo faltava; apesar de toda alegria e paz, não poderia deixar de ser um estranho a tudo" e não conseguia "deixar de ser o que era: estranho" (MARTINS, 1981, p. 82). Até que uma noite, descobriu o segredo que the impedia de deixar de ser um estranho, estrangeiro. O celibato era difícil, a tortura das noites longas e solitárias insuportável e Padre Alexandre, a quem ele tinha ido substituir, tinha arranjado uma mulher e possuía já vários filhos. Pela primeira vez, percebeu que padres tinham corpos e eram homens. Pediu para sair de Ibiamoré e foi mandado para Guanambi, onde foi recebido com um santo, mas não resistiu. Era tratado como o santo que parecia ser perante aquele povo humilde e sentiu o peso da santidade. Não sentindo-se santo, caiu em tentação, pois já não conseguia mais negar o corpo que tinha. Aceitou uma mulher, pois já não agüentava mais as noites em claro. Tiveram três filhos, um por ano. O narrador comenta que "Sua missão lhe parecia mais importante do que qualquer outra - uma espécie de chefe, santo, médico, cacique e pajé" (MARTINS, 1981, p. 89). 
Mas um dia sua missão foi interrompida pela visita de um padre espanhol chamado de Frei Esteban Cortes, e ele teve que esconder mulher e filhos, sentindo-se como Padre Alexandre havia sentido-se quando José chegara à sua paróquia. E padre Esteban, sem saber, havia trazido a vida da cidade à Guanambi e na mente de Padre José, "Um mundo, até então morto, recomeçara a viver, intruso e exigente, nos campos de Guanambi. Um mundo qual fugira, mas a que, de fato, pertencia; o encanto se quebrara, a fragilidade de um pássaro atingido por uma pedra minúscula" (MARTINS, 1981, p. 90). Então empreendeu nova viagem. Ele havia sido feliz em Guanambi, após deixar de ser estrangeiro, mas havia preferido voltar à cidade e confessar seus pecados. Padre José "arrependia-se muito - e, no fundo, também não" (MARTINS, 1981, p. 91), mas havia descoberto que não se foge do passado ou, talvez, como diria dona Carlinda, de seu destino.

Padre José retorna à Guanambi já maduro. Inventa um pretexto, e toma o trem para a região de Ibiamoré. Mas Guanambi foi perdida, não há mais nada em seu lugar. Chega a perguntar-se se "Estará sonhando?" ou "Terá inventado toda uma vida, uma aldeia que nunca existiu? (MARTINS, 1981, p. 92). Assim como Almagre, ele também pergunta-se sobre a sua própria vida, que parece irreal e questiona sua própria memória. Seriam todas as cenas que lembrara apenas falsas memórias ou memórias encobridoras, a encobrir um passado que nunca havia existido? Parece que a única criança sobrevivente, uma menina clara, que supõe ser sua filha, havia sido levada para Gastonville. Talvez esta fosse a única prova de seu passado, pois todas outras pegadas foram apagadas. Padre José pensa:

O passado inteiro, presente e não percebido, e o futuro que ainda não conhecia: a marcha para o nada, a sensação da vida posta fora, o amargor de tudo que poderia ter sido e que não deixará acontecer, a rota interrompida, os anos todos de ignorância do que pensava saber e não sabia, Guanambi perdida. $\mathrm{E}$, além, disso, a saudade que o levaria a empreender a segunda viagem para Ibiamoré, em busca de um passado que repudiara (MARTINS, 1981, p. 79).

Padre José some da narrativa, como se tivesse entrado no trem fantasma e somos apresentados a novos passageiros. Uma das personagens que conhecemos e que podemos considerar como uma das personagens centrais do romance é Amanda Müller Schmidt. Ela aparece, mesmo que apenas como fantasma, em diversas estações da narrativa. Amanda é mais uma personagem que foge de seu passado, deixando sua cidade, seu marido e sua filha, e partindo com certo Cândido. Abandona a vida respeitável e aparentemente perfeita para ser amante, após sentir que algo lhe falta. Cândido e Amanda mudam-se para Gastonville, onde Cândido dirige 
o cinema e Amanda passa o tempo todo lendo e escrevendo em seu diário. Apenas à noite, embeleza-se e vai ao cinema com Cândido, para depois escrever comentários sobre eles em seu diário. Então, as narrativas em seu diário começam a ficar cada vez mais confusas anunciando o que viria a seguir. Cândido abandona Amanda subindo em um barco no cais do porto e desaparecendo misteriosamente, assim como havia aparecido. Amanda encontra então o novo gerente do cinema, Achylles, e vira também vira sua amante. Mas Achylles também abandona a bela e misteriosa Amanda, pois não suporta as pressões da cidade para que case com uma moça distinta. Amanda não suporta esse abandono e entra em um período de decadência e enlouquecimento e então, desaparece. O narrador classifica o noivado de Achylles com uma moça da cidade como a "derrota da estrangeira" (MARTINS, 1981, p. 118), mas Achylles também não suporta ficar com outra, e longe de Amanda, e também some. O sumiço de Amanda permanece um mistério indecifrável já que seu corpo é jamais encontrado. Cria-se, então, a lenda de uma mulher, um fantasma de mulher, que passeava à noite nas terças-feiras de carnaval. Havia ela também entrado no trem do desaparecimento? Mas Amanda reapareceria no romance, como todos outros passageiros de Martins. Juventina, a empregada da então decadente Amanda, havia sido a empregada de Dona Carlinda, a bonequeira, que havia fugido de Santa Joana e, quem sabe, de dona Carlinda, entregandose à bebida. $\mathrm{O}$ narrador deixa-nos curiosos. Quantos segredos guardaria Juventina?

Amanda como todos os personagens do romance fez um trajeto, uma viagem. Saiu da pequena Três Cascatas de maneira inusitada, deixando sua vida para trás, e no noturno de Ibiamoré, o seu trem fantasma, foi até Porto Alegre, e de lá viajou até Gastonville, onde talvez tenha terminado sua viagem. Amanda entrou no trem e em busca de uma outra vida, perdeu a sua. Seu deslocamento físico, de trem, representa um outro deslocamento. Sua travessia. Mais adiante, o narrador do romance comenta a foto de Amanda aos três anos de idade e pergunta: "Amanda antes da sua história - cresceria para vivê-la se a tivesse conhecido?" (MARTINS, 1981, p. 123) e revela como se ficara sabendo da história de Amanda. Ela mantinha o diário em um caderno de couro roxo, mas após seu desaparecimento esse caderno foi parar nas mãos da bibliotecária e não é nunca catalogado. A bibliotecária lê o diário de Amanda e talvez tenha posse dos segredos não revelados ao leitor. $O$ narrador parece saber mais do que nos conta e o mistério de Amanda cresce. Pergunta-se se teria ela enlouquecido de tanto ver filmes e fingir que era uma triz. Teria frustrando-se em não ter a vida das estrelas que imitava? A bibliotecária lê uma carta da mãe de Amanda a ela logo após a sua fuga e também a carta da mãe de Amanda ao seu irmão. 
Junto com esta carta está uma foto de Amanda ainda bebê com uma assinatura atrás. A foto havia sido tirada por um fotógrafo itinerante da época, fato que aponta mais uma vez para organização associativa e não temporal do romance, já que viajantes de Martins sempre deixam suas marcas e voltam.

A foto de Amanda ainda bebê havia sido tirada por Gutierrez. Ele é um dos muitos estrangeiros no romance que se perdem por Ibiamoré. Gutierrez morre ao ir reencontrar sua família após uma longa separação. Sonha que morrem todos no trem e lembra da linda menina de quem havia tirado fotos. Pensa se seu nome teria siso Amanda, Amália? E morre no trem indo em busca de sua felicidade. Sua mulher jamais ficaria sabendo o que houve a ele. Gutierrez torna-se mais um fantasma pairando, mas um a entrar no trem e lá permanecer. Mas pode-se dizer que Gutierrez foi provado do reencontro e de possíveis desencontros, com sua família, e morreu antes de conhecer a sua história.

Outros viajantes que perdem-se pelas terras de Ibiamoré encontrando seus destinos são Madame Delorme e Chico Doce. Apesar de vidas totalmente diferentes têm muito em comum, pois tentaram voltar a um momento único de seus passados e fracassaram. Madame Delorme e seu amigo Carlos domingos de Abreu conheceram-se quando jovens e trocaram correspondências por longos anos. Já na meia-idade, decidiram-se reencontrar-se, mas esse encontro foi marcado pela decepção. Madame Delorme esperava encontrar o belo Abreu da juventude e deparou-se com um homem de meia-idade, "um velho careca e debochado" (MARTINS, 1981, p. 241). Este, por sua vez, esperava encontrar uma intocada Delorme, mas deparou-se com uma matrona. Ambos percebem que, "foi tolice querer reviver um passado que devia ser lembrado somente pela memória” (MARTINS, 1981, p. 243). Percebem que não passarão jamais pelos mesmos trilhos que um dia passaram, mas mesmo assim, para desespero de Delorme, Abreu pede a filha de Delorme em casamento. Ela recusa-o e a amizade termina. É o passado que nunca volta e nunca vai embora.

Chico Doce cometeu o mesmo erro. Apaixonou-se por Frederika, "uma moça que falava atrapalhado e só mostrava as canjicas" (MARTINS, 1981 , p. 205) e soube que ela era "mulher pra toda vida, mulher de um homem só" (MARTINS, 1981, p. 207), mas fugiu da felicidade e do destino, tentando não deixar marcas e não se marcar. Somente "quando foi embora, se deu conta" (MARTINS, 1981, p. 206) de que "a felicidade máxima não volta nunca mais, por que?" (MARTINS, 1981, p. 208). Chico "achou seu destino e teve medo" (MARTINS, 1981, p. 210), não podia subjugar-se a ele e "fugia dela para conservar a lembrança" (MARTINS, 
1981, p. 210). Essa tentativa de fuga da paixão por Frederika revela-se frustrada, como o poema Apaguem as Pegadas de Belthold Brecht, trazido por Jeanne Marie Gagnebin, ironicamente nos mostra. Há uma impossibilidade de remover todas as pegadas, assim como há uma impossibilidade de reviver os momentos passados da mesma maneira que foram uma vez vividos. Apagar as pegadas seriam renegar toda uma existência, travessia, e as marcas desta no sujeito. O poema de Brecht diz:

Separe-se de seus amigos na estação

De manhã vá a cidade com o casaco abotoado

Procure alojamento, e quando seu camarada bater:

Não, oh, não abra a porta

Mas sim

Apague as pegadas!

Se encontrar seus pais na cidade de Hamburgo ou em outro lugar

Passe por eles como um estranho, vire na esquina, não os reconheça

Abaixe sobre o rosto o chapéu que eles lhe deram

Não, oh, não mostre seu rosto

Mas sim

Apague as pegadas!

Coma a carne que aí está. Não poupe.

Entre em qualquer casa quando chover, sente em qualquer cadeira

Mas não permaneça sentado. E não esqueça seu chapéu.

Estou lhe dizendo:

Apague as pegadas!

O que você disser, não diga duas vezes.

Encontrando o seu pensamento em outra pessoa: negue-o

Quem não escreveu sua assinatura, quem não deixou retrato

Quem não estava presente, quem nada falou

Como poderão apanhá-lo?

Apague as pegadas!

Cuide, quando pensar em morrer

Para que não haja sepultura revelando onde jaz

Com uma clara inscrição a lhe denunciar

E o ano de sua morte a lhe entregar

Mais uma vez: Apague as pegadas!

(Assim me foi ensinado.)

Jeanne Marie Gagnebin também nos lembra da afirmação de Walter Benjamin de que "habitar é deixar rastros" (GAGNEBIN, 1991, p. 68) e a relaciona ao poema Brecht, que trata desse ambíguo desejo do indivíduo de deixar marcas no mundo e de apagá-las sempre que lhe causem desprazer. As marcas, os rastros, às vezes incomodam. Chico volta a 
procurar Frederika, aquela que o tinha marcado e assustado, mas ela finge não o reconhecer na companhia de seu marido. A conclusão da negação é a de que "Só há uma Frederika na vida", "Antes toda a sua vida era chegar, agora sabia que toda ela ia ser ir embora, embora", pois "depois não dá para voltar" "Sabe que mudou o destino, a hora já foi vivida e nunca mais" (MARTINS, 1981, p. 211). É o passado que não volta, mas que ao mesmo tempo não vai embora; as pegadas que não podem ser apagadas e $o$ caminho que não pode ser tomado, como nos mostra o poema "O caminho não tomado" do poeta norte-americano Robert Frost. No poema de Frost, para cada caminho tomado, há outro não escolhido que permanecerá misterioso na nossa imaginação fazendo com que a cada intersecção nos questionemos sobre qual a melhor alternativa.

A conclusão do poema parece ser a de que a vida é feita de opções e para cada caminho tomado, cada estação em que desembarcamos, há um outro, que permanecerá desconhecido. Ainda, o psicanalista Ricardo Mezan também nos traz que a vida é por si só uma viagem cheia de bifurcações e escolhas de caminhos. Há uma trajetória da infância à idade adulta na nossa vida e desta à velhice. Mas segundo Mezan: "a cada encruzilhada, a cada bifurcação, o trajeto podia ter sido outro, e este é o ponto essencial" (MEZAN, 1991, p. 70), segundo ele.

Esta é a mesma situação descrita por Flora Süssekind referindose a Maria Graham e seu reencontro com a paisagem de Funchal e o estranhamento provocado por esse reencontro. Marta descreve uma "sensação de que houvera uma mudança, seja na paisagem, seja em min" (SÜSSEKIND, 1990, p. 105). Süssekind também faz referência aos movimentos auto-reflexivos encontrados no texto de Graham, que também estão presentes em Martins. De acordo com Heloísa Fernandes, "retornar não é reencontrar, pois o retorno está sempre um passo adiante... Intervalo... Travessia..." (FERNANDES, 1988, p. 19) e "rememorar não é somente repetir, mas sobretudo, diferenciar (FERNANDES, 1988, p. 20). Há uma necessidade de "encontros criativos com o passado, enterrado, mas não morto" (FERNANDES, 1988, p. 20), que precisa ser revisitado porque o que encontramos quando retornamos nunca é aquilo que deixamos. Ainda segundo Fernandes, nem mesmo nos reencontramos pois já somos outros, embora muitas vezes neguemos e procuremos ser os mesmos (FERNANDES, 1988, p. 24). Tanto Delorme quanto Chico Doce pensaram que voltar a uma cena similar àquela do passado traria o momento rememorado de volta, mas já eram outros e o momento não voltaria jamais. Era hora de outros momentos e talvez tivesse sido melhor se aqueles momentos tivessem ficados apenas na memória, como recordações e, talvez, histórias a serem contadas. 
A narrativa de Martins prossegue com suas paradas e bifurcações. Há a introdução de novos personagens e cronistas da lenda do trem fantasma que são também, personagens do romance. O cronista Leonardo Salles nos traz um tropeiro que teria sido o único a sair vivo do trem. Ele havia visto o trem inteiro e vazio, e conhecendo a lenda, temia-o. Mas impelido por uma curiosidade que o vencia, entrou no trem. E na semi-obscuridade do trem, viu a cena tantas vezes descrita, da armadilha armada. Fazem-lhe uma pergunta e dizem-lhe: "Se não disseres, terás o fim de todos os outros!"(MARTINS, 1981, p. 169). O velho tropeiro de repente vê a verdade e a diz e "o trem todo como que se dissolve; parece ter havido um grande desastre; vê-se precipitado novamente ao solo. Ergue-se, não há sinal do trem, do acidente, de nada" e tem a certeza de que "o Trem não passará mais para ele. Junto a esta, tem outra certeza: estará a salvo apenas enquanto não revelar a ninguém a resposta dada" (MARTINS, 1981, p. 169). O velho tropeiro havia estado em uma bifurcação, como tantas que temos na vida, e havia feito a escolha certa. Segundo o narrador, o velho peão havia visto a verdade e esta teria dado-lhe a resposta, mas a verdade não é sempre tão evidente ou visível.

Há também o Doutor Canabarro da Silva, que havia sido mencionado no capítulo anterior como um médico, deitado em seu leito de morte. Canabarro olha a mulher sentada na beira de sua cama e percebe que é uma velha. Pensa: "como pudera desejá-la antes?" e reconhece que "recordá-la é lembrar a si mesmo" (MARTINS, 1981, p. 184), é lembrar o homem que já foi e que o tempo escondeu. Pensa no trem que parece chegar para conduzi-lo para sua última viagem e no seu futuro:

Felizmente não acredita em nada - nada a não ser o repouso e o fim. Pena, uma vida só. Alguma injustiça mesmo-apenas uma. E, ao terminar, fïm para tudo-o mundo se desfazendo em nada. Nada restando. Somente sue corpo. Algo tão alheio, nada a ver consigo, que será estendido no meio da sala, as janelas fechadas, velas ardendo, recebendo visitas e, falsas tristezas e verdadeiras (MARTINS, 1981, p. 185).

Canabarro segue pensando sobre sua vida e reconhece que viveu muito. Ele havia vivido, diferentemente de muitos que havia deixado no passado, "sua vida, uma vida inteira - não morreu antes de viver preparando-se para isso" e "agora, chegava a sua vez" (MARTINS, 1981, p. 185). Pensa na sua viagem de Portugal ao Brasil e na viagem através dos anos vividos. Pensa no tempo em que a velhice era "uma senhora distante nalguma ilha perdida da Oceania" e a morte "um abismo escondido nalguma geleira remota da Finlândia", ambas "impossíveis quase, exóticos - fantasmas que não se vêem" (MARTINS, 1981, p. 186). E pensa no traçado de suas próprias trajetórias, deslocamentos, em tantas linhas confusas; lembra dos anos perdidos e percebe que "não haverá amanhã" para seu corpo (MARTINS, 
1981, p. 188) pois o trem havia chegado. Esta era a derradeira parada.

Se lermos o romance na ordem sugerida por sua encadernação, a última parada do romance é Porto Saibro. Ela inicia-se com uma epígrafe, como todos os capítulos, que é o poema apresentado nas páginas iniciais do romance. Esse poema introduz a lenda do trem fantasma, mas aqui ele é apresentado completo e é referido como uma cantiga do folclore de Ibiamoré. A seguir, há uma nota sobre o autor que teria cunhado esses versos e também o romance. Nesta estação final, o narrador assume ser apenas um compilador dos textos de Aquiles, e conta um pouco da história desse Aquiles. Talvez seja ele Aquiles antes de Amanda. Um Aquiles que tinha perdido os pais ainda menino em uma epidemia. O seu casamento aos 25 anos, a gravidez da esposa não levada a termo, e a esposa que o havia abandonado. Pensamos se ele tivera abandonado Amanda e depois sua noiva por medo de ser ele deixado. Aquiles, que havia sido criado em uma casa cheia de potes coloridos, por sua tia excêntrica, uma tal de Dona Carlinda, que já conhecemos de perto. Ou talvez um Aquiles que não abandonou Amanda, mas que morreu ao ir procurá-la. Surgem dúvidas. O último amante de Amanda teria se chamado Achylles e não Aquiles? Seria esse Aquiles Gama o amante de Amanda ou tudo seria "coincidência", como o narrador nos coloca em uma das últimas páginas? Teria ele sido o autor de tudo e teria atribuído os poemas a seus personagens, como sugere o narrador dizendo questionando se "seriam os personagens fictícios a plagiarem seu criador -ou ele, o plagiário de seus biografados?" (MARTINS, 1981, p. 325). Na última página deixada por esse Aquiles estava escrito, "chegou a hora, o trem está na estação e devo subir" (MARTINS, 1981, p. 330) Não há mais tempo para nada, apenas para registrar sua história. Entretanto, não podemos esquecer de notar que a devido à circularidade do romance, a última parada, não é necessariamente a derradeira. Podemos iniciar a leitura do romance em qualquer estação e escolher um final.

\section{ACHEGADA}

O presente não existe. Não acaba. Não termina. O passado nunca passa, é a taça que se inclina. O futuro está na frente. Mas, presente, é sempre ausente.

O passado não nos deixa, Mando embora e ele insiste. Píndaro Escoriel 
Podemos concluir que o romance de Martins parece propor-se a oferecer uma narrativa sobre a lenda do trem fantasma sem tentar oferecer nenhuma versão definitiva e usando-a como pretexto e, porque não, prétexto. Ele faz uso de um narrador aparentemente neutro em terceira pessoa que parece olhar tudo de fora da narrativa e simpatizar com seus personagens. Mas entre esses personagens habilmente criador por Martins alguns deles são os supostos narradores da lenda, que são apresentados, acima de tudo, como sujeitos. Martins oferece diferentes relatos e versões da lenda e de seus cronistas através desses narradores, contando a história da lenda assim como a história daqueles que a contaram, que se debruçaram sobre ela, fazendo relações entre a lenda e seus cronistas. Há uma constante reiteração de informação para que a história possa ser contada de diferentes maneiras. Assim, a narrativa é totalmente circular: avança e volta a cada momento. O narrador preocupa-se em questionar as informações apresentadas pelos inúmeros contadores da lenda e também em identificar de que posição fala cada contador e porque ele conta a lenda. O mesmo que Martins nos convida a fazer no fim do romance. Mas o romance não é e não deve ser comparado com um romance histórico, pois não busca estabelecer uma história oficial, mas propõe uma discussão sobre a importância de contar versões de uma história. No final do romance, quando todo o texto é atribuído a um outro, e o nosso narrador revela-se um compilador, há uma mudança de perspectiva e a figura do narrador imparcial é destituída.

De uma certa maneira, a narrativa de Martins não enfatiza a lenda do trem fantasma ou trem da noite e suas inúmeras versões, mas como se conta lendas, de onde elas vêm, como são transmitidas e porque se conta lendas. Os narradores da lenda são sujeitos as voltas com a sua própria história e com os seus próprios medos e são apresentados como falhos, fracos, faltantes, humanos e suscetíveis a entrar no trem a qualquer momento e deixar nossa história incompleta. Como Píndaro Escoriel, cujo poema apresentado acima é um exemplo. Píndaro bêbado não consegue lembrar a ordem das estrofes e recita-as diversas vezes de maneiras diferentes. Ficamos sem saber qual seria a ordem pretendida por ele e tudo que temos são versões do mesmo poema, mas para Martins isso não parece importar.

Outro exemplo claro é João José Cohimbra, supostamente o primeiro a narrar a lenda, que é aquele que tem que fugir, entrar também no trem, por ter molestado a jovem Carlinda, não tendo conseguido controlar seus impulsos e tendo jogado fora sua boa reputação na cidade achando que ele e Carlinda haviam sido reunidos pelo destino. Ele pensa: "o destino nos reuniu" e "Não sabe porque nem como. Mas sabe que é impossível evitar o que acontece" (MARTINS, 1981, p. 35). José João foge para o 
Uruguai e morre lá em um acidente de trem. "La forza del destino" diz o narrador. Essa parece ser uma das questões essenciais do romance, o trem como uma metáfora para a morte, para o destino, em sua inabalável marcha e com a sua maneira singular de arrecadar passageiros.

Há também incontáveis momentos autoconscientes, em que o próprio desejo de contar uma narrativa é questionado pelo narrador. "Afonso Inácio terá algum dia existido? Toda uma vida inventada, falsa, inexistente, criada para ser nada, coisa nenhuma" (MARTINS, 1981, p. 28) e "Para que escrevê-la?" (MARTINS, 1981, p. 29), pergunta Padre Cortoxines, em uma reflexão acerca do papel do historiador e do ato de contar. Quem ouvirá? Esse questionamento leva-nos as já mencionadas páginas finais do romance, onde o ancião sentado à beira do fogo não encontra ouvintes para suas histórias e seu fogo se apaga.

Outro momento do romance em que há questionamentos acerca do ato de escrever é no capítulo intitulado "Klapp, Escoriel: Falsas mentiras". Escoriel havia escrito um livro e pediu ao amigo Klapp que the desse a sua opinião sobre o texto. Klapp, após ler o texto, pergunta a Escoriel por que razão ele havia inventado detalhes e fatos se as histórias já eram boas o suficiente. Klapp insiste: "Por que não podes contar só a verdade?" (MARTINS, 1981, p. 149) Escoriel defende-se dizendo que são "falsas mentiras" ou "mentiras falsas" e ainda questiona a existência da verdade. O mesmo questionamento é feito no fim do romance quando é dito que Aquiles visita Santo Onofre em busca da verdade sobre a lenda do trem e é obrigado a aceitar que só há lendas, relatos desencontrados cuja origem parece há muito já ter sido perdida.

Nosso narrador já nos indicava esse caminho de leitura. Logo no começo do romance, lemos; "Não podemos diferenciar o que terá havido do que terá sido imaginado" (MARTINS, 1981, p. 27). Mas mais adiante há uma aparente contradição: "Diferentemente da ficção, onde se chega a conhecer até o mais íntimo pensamento dos personagens, a realidade se esconde, oculta, e nela não se chega à certeza de nada". Na verdade, não há contradição, pois a única realidade a qual temos acesso enquanto leitores é a do texto. E nosso narrador faz com que percebamos que na ficção não chegamos a conhecer tudo, apenas os limites da ficção a qual temos acesso.

No fim do romance está colocada uma das questões principais do romance. Seriam os personagens fictícios a plagiarem seu criador (Aquiles) ou Aquiles o plagiário de seus biografados? Nosso narrador comenta, "É a lenda incidindo sobre si mesma e criando em si própria, imagens novas como luz que, refletida na superfície de um espelho, tem o próprio reflexo transcrito e a própria intensidade aumentada" (MARTINS, 1981, p. 325). 
Se as colocações feitas anteriormente forem levadas em consideração, podemos dizer que Ibiamoré, o trem fantasma pode ser considerado um romance autoconsciente e auto-reflexivo, pois dramatiza e ao mesmo tempo encapsula o seu próprio contexto, adequando-se ao conceito de romance auto-reflexivo de Stonehill (STONEHILL, 1988, p. 9). Há no romance a estrutura chamada de mise-en-abysme por Gide e cujo exemplo mais famoso é o Hamlet de Shakespeare onde há uma peça dentro de uma peça. Em Martins, temos um romance dentro de um outro romance, havendo uma duplicação de estrutura como em Hamlet. Há o livro de Aquiles dentro do romance de Martins, e dentro desses dois há fragmentos de Chica del Tren e de A Bergamoteira. A história do texto e uma possível história de sua escritura estão colocadas dentro do próprio texto e problematizadas.

Federman lembra-nos que todos os textos são, até um certo ponto, sobre si mesmos. Assim, todos são sempre até um certo ponto reflexivos (FEDERMAN, 1996, p. 1143). Mas em alguns textos estas questões vêm mais à tona e são problematizadas pelo autor. Portanto, há uma problematização da relação entre história e realidade e entre realidade e linguagem em Ibiamoré, o trem fantasma. O comentário de nosso narrador sobre a identidade de Aquiles confunde-nos. Há mais uma dúvida. Nós, leitores, somos levados a questionar a veracidade de uma história contada por um tal Aquiles. Ou indo ainda mais além, somos levados a acreditar que a verdade não tem nenhuma importância. O que talvez importe seja a travessia até que o trem chegue, pois segundo Lacan, "A vida é isto-um rodeio obstinado, em si mesmo, transitório e caduco, e desprovido de significação" (LACAN, 1987, p. 292).

Assim, os campos de Ibiamoré não parecem ser uma região física, mapeável, mas imaginária, por onde todos caminhamos ou viajamos. Uma região de nossas próprias histórias, atormentada pelo nosso próprio trem fantasma que nos força a tomar decisões e dar a resposta certa a todo o momento. Mas afinal qual é a lenda do trem fantasma? Podemos perguntar. Tudo que sabemos é que há um trem a correr os campos de Ibiamoré e a puxar a todos para dentro de um de seus vagões através de suas fraquezas, sejam elas a bebida, o jogo, mulheres bonitas, uma dança. Quem não tomar a decisão certa é forçado a permanecer dentro do trem sumindo de sua vida de repente. Não é por acaso que é também chamado por seus cronistas de trem da noite ou trem da morte.

Lá vem vindo o trem da noite, vem da vida vai pra morte.

Já vai indo o trem da noite, Vai pra vida, vem da morte. 


\section{BIBLIOGRAFIA}

FEDERMAN, Raymond. Self-reflexive Fiction. In: The Columbia literary history of the United States. New York, Columbia University Press, 1996.

FERNANDES. Heloísa. Temporalidade e subjetividade. In: FERNANDES, Heloisa (org). Tempo do desejo: Sociologia e Psicanálise. São Paulo, Brasiliense, 1988.

GAGNEBIN, Jeanne M. História e narração em Walter Benjamin. São Paulo, Perspectiva, 1994.

GOLDENBERG, Ricardo. Pós-moderno \& psicanálise (\& vice-versa). In: CHAlHUB, Samira (org). Pós-moderno \&. Rio de Janeiro, Imago, 1994.

HARTOG, François. O Espelho de Heródoto. Ensaio sobre a representação do Outro. Belo Horizonte, Editora UFMG, 1999.

HUTCHEON, Linda. The poetics of postmodernism. New York and London, Routledge, 1995.

IANNI, Octavio. A metáfora da viagem. Cultura: Vozes, v. 90, n. 2, p. $3-$ 19, mar/abr 96.

LACAN, Jacques. O Seminário. O eu na técnica de Freud e na técnica da psicanálise. Rio de Janeiro, Zahar, 1987.

MARTINS, Roberto Bittencourt. Ibiamoré, o Trem Fantasma. Porto Alegre, LPM, 1981.

MEZAN, Renato. Diálogo com Loparic. In: KNOBLOCH, Felícia (org). O Inconsciente: Várias Leituras. São Paulo, Escuta, 1991.

SCHNEIDER, Michel. Ladrões de Palavras. Campinas, Editora da Unicamp, 1990.

STONEHILL, Brian. The self-conscious novel: Artifice in Fiction from Joyce to Pynchon. Philadelphia, University of Pennsylvannia Press, 1988.

SÜSSEKIND, Flora. O Brasil não é longe daqui. O narrador, a viagem. São Paulo, Companhia das Letras, 1990. 